\title{
PEMETAAN AIR SUMUR BOR BERDASARKAN STANDAR KUALITAS AIR MINUM PADA MASYARAKAT KELURAHAN WOWAWANGGU KECAMATAN KADIA KOTA KENDARI
}

\author{
Alimatul Izzah ${ }^{1}$ \\ ${ }^{1}$ Alumni Pendidikan Geografi FKIP UHO
}

\begin{abstract}
Abstrak : Penelitian ini bertujuan untuk mengetahui kualitas air sumur bor dari parameter fisika yaitu: suhu, kekeruhan dan TDS (Total Dissolued Solids), kualitas air sumur bor dari parameter Kimia yaitu: pH (Potential Hydrogen), besi (Fe), Seng ( $\mathrm{Zn})$ dan kesadahan ( $\mathrm{Mg}$ $\mathrm{CaCO}_{3}$ ), kualitas air sumur bor dari parameter Mikrobiologi yaitu bakteri Escheria Coli dan total coliform, dan untuk mengetahui Sebaran kualitas air sumur bor di Kelurahan Wowawanggu. Jenis penelitian ini adalah kualitatif deskriptif, dengan metode atau pendekatan Studi Kasus (Case Study). Fokus dalam penelitian ini adalah kualitas air sumur bor masyarakat Kelurahan Wowawanggu Kecamatan Kadia Kota Kendari. Obyek dalam penelitian ini adalah air sumur bor masyarakat yang memiliki kedalaman 50 - 100 meter, terletak di Kelurahan Wowawanggu, Kecamatan Kadia, yakni RT 13 RW 04, RT 09 RW 03, RT 01 RW 01, RT 06 RW 02 dan RT 15 RW 05. Teknik pengambilan sampel ditentukan dengan teknik purposive sampling. Hasil dari penelitian didapatkan bahwa Kualitas air sumur bor secara fisik yang terdiri dari parameter suhu, kekeruhan, dan TDS memenuhi syarat untuk dikonsumsi, kualitas air sumur bor secara kimia yang terdiri dari Parameter $\mathrm{pH}$ (potential of hydrogen), Seng $(\mathrm{Zn})$, dan Kesadahan $\left(\mathrm{Mg} \mathrm{CaCO}_{3}\right)$ memenuhi persyaratan untuk dikonsumsi tetapi untuk parameter besi $(\mathrm{Fe})$ tidak memenuhi syarat untuk dikonsumsi. Hasil uji kualitas air sumur bor dari parameter mikrobiologi yang terdiri dari bakteri Escherichia coli dan total coliform tidak memenuhi syarat untuk dikonsumsi. Pemetaan kualitas air dengan berbasis sistem informasi geografis memudahkan dalam pemantauan kualitas air sumur bor bagi masyarakat Kelurahan Wowawanggu Kecamatan Kadia Kota Kendari.

Kata Kunci : Kualitas, air sumur bor, masyarakat Kelurahan Wowawanggu, Kecamatan Kadia, dan pemetaan.
\end{abstract}


Jurnal Penelitian Pendidikan Geografi Volume 4 No 2 April 2018

\title{
WATER WELL MAPPING BASED ON STANDARDS QUALITY OF DRINKING WATER IN COMMUNITY WOWAWANGGU DISTRICT KADIA SUBDISTRICT KENDARI CITY
}

\author{
Alimatul Izzah ${ }^{1}$ \\ ${ }^{1}$ Alumni Of Geography Education Faculty Of Education UHO
}

\begin{abstract}
This study aims to determine the water quality of bore wells from physical parameters, namely: temperature, turbidity and TDS (Total Dissolued Solids), water quality of bore wells from chemical parameters namely: $\mathrm{pH}$ (Hydrogen Potential), Iron (Fe), Zinc $(\mathrm{Zn})$ and hardness (Mg CaCO3), water quality of bore wells from Microbiology parameters namely Escheria Coli bacteria and total coliform, and to determine the distribution of water quality of bore wells in Wowawanggu village. This type of research is qualitative descriptive, with a Case Study method or approach. The focus in this study is the quality of community wellbore water in Wowawanggu Village, Kadia Subdistrict, Kendari City. The object in this study is community well drilling water which has a depth of 50-100 meter, which is located in Wowawanggu Village, Kadia Subdistrict, namely RT 13 RW 04, RT 09 RW 03, RT 01 RW 01, RT 06 RW 02 and RT 15 RW 05. The sampling technique was determined by purposive sampling technique. The results of the study found that the physical quality of the wellbore well consisting of parameters of temperature, turbidity and TDS fulfilled the requirements for consumption, the quality of drilled well water chemically consisting of $\mathrm{pH}$ parameters (potential of hydrogen), zinc $(\mathrm{Zn})$, and hardness $(\mathrm{Mg} \mathrm{CaCO})$ fulfilled the requirements for consumption, but iron $(\mathrm{Fe})$ parameters do not fullfill the requirements for consumption. The results of the drill well water quality test from microbiological parameters consisting of Escherichia coli bacteria and total coliform did not fulfill the requirements for consumption. water quality mapping based on geographic information systems makes it easy to monitor the quality of drilled well water for the community of Wowawanggu village, Kadia Subdistrict, Kendari City.
\end{abstract}

Keywords: Quality, wellbore water, Wowawanggu Village community, Kadia Subdistrict, and mapping.

\section{PENDAHULUAN}

Air merupakan bahan yang sangat vital yang tidak dapat dipisahkan dari seluruh aktivitas kehidupan makhluk hidup di bumi ini. Keseluruhan jumlah dari 40 Juta mil kubik air yang berada di planet bumi ini, baik yang berada di dalam atau di permukaan ternyata hanya $0,5 \%$ atau 0,2 juta mil kubik yang secara langsung dapat digunakan. Sisanya yaitu $97 \%$ berbentuk air laut dan $25 \%$ berbentuk salju dan es abadi yang dalam keadaancair baru dapat digunakan (Suriawiria, 2005).
Air merupakan kebutuhan dasar dan bagian dari kehidupan yang fungsinya tidak dapat digantikan oleh senyawa lain, dengan demikian layak untuk diketahui kandungan air tersebut, dengan melakukan uji kualitas air melalui beberapa parameter yaitu: fisika, kimia dan Mikrobiologi.

Saat ini, masalah utama yang dihadapi oleh sumber daya air meliputi kuantitas air yang sudah tidak mampu memenuhi kebutuhan yang terus meningkat. Dahulu kebutuhan air telah dapat tercukupi hanya dengan 
menggunakan sumur gali tetapi seiring dengan meningkatnya aktivitas manusia di bidang industri, domestik, dan kegiatan lain, maka sudah tidak lagi mencukupi sehingga digunakanlah sumur bor.

Kelurahan Wowawanggu merupakan salah satu kelurahan yang ada di Kecamatan Kadia Kota Kendari. Data dari Badan Pertahanan Nasional Kota Kendari menunjukkan luas Kelurahan Wowawanggu $1,45 \mathrm{~km}^{2}$ dimana luas wilayahnya menempati urutan keempat setelah Kelurahan Kadia, Bende dan Pondambea Kecamatan Kadia. Angka proyeksi penduduk tahun 2010 menunjukkan jumlah penduduk Kelurahan Wowawanggu 6.549 jiwa dimana kepadatan penduduk $4.516,55$ per $\mathrm{km}^{2}$. Sumber air yang digunakan oleh masyarakat Kelurahan Wowawanggu sebagian besar berasal dari air tanah dalam atau sumur bor. Berikut ini Data Sumber Air Bersih Masyarakat Kelurahan Wowawanggu.

Tabel 1.1 Data sumber air bersih masyarakat Kelurahan Wowawanggu

\begin{tabular}{llll}
\hline Jenis & Jumlah (Unit) & Pemanfaat (KK) & Kondisi (Baik/Rusak) \\
\hline Sumur Gali & 406 & 509 & Baik \\
\hline Sumur Bor & 119 & 119 & Baik \\
\hline Depot Isi Ulang & 7 & 455 & Baik \\
\hline
\end{tabular}

(Sumber: Profil Kelurahan)

Berdasarkan hasil observasi yang dilakukan terhadap beberapa air sumur bor yang digunakan oleh masyarakat yang tinggal di Kelurahan Wowawanggu Kecamatan Kadia Kota Kendari adalah kondisi air yang digunakan agak berbau dan berwarna agak kecokelatan sehingga dapat meninggalkan noda cokelat atau membuat pakaian menjadi kekuningan. Selain itu beberapa sumur juga harus dilengkapi dengan alat penyaring. Untuk itu penelitian ini bertujuan untuk mengetahui kualitas fisika, kimia maupun Mikrobiologi pada air sumur warga tersebut.

\section{Air Tanah Dalam}

Air ini berasal dari lapisan air kedua di dalam tanah. Dalamnya dari permukaan tanah biasanya di atas 15 meter. Pada umumnya kualitas air tanah dalam lebih baik dari pada air tanah dangkal karena terjadi penyaringan yang lebih sempurna terutama untuk bakteri. Oleh karena itu, sebagian besar air tanah dalam sudah bisa dikonsumsi secara langsung tanpa pengolahan (Notoatmodjo, 2003:155).

Pengambilan air tanah dalam tidak semudah air tanah dangkal. Dalam hal ini menggunakan bor dan memasukkan pipa ke dalamnya hingga pada kedalaman tertentu (50-100 meter). Kualitas air tanah dalam pada umumnya lebih baik dari pada air tanah dangkal, karena penyaringannya lebih sempurna dan bebas dari bakteri.

\section{Air Sumur Bor}

Dengan cara pengeboran, lapisan air tanah yang lebih dalam ataupun lapisan tanah yang jauh dari permukaan dapat dicapai sehingga sedikit dipengaruhi kontaminasi. Umumnya air ini bebas dari pengotoran oleh Mikrobiologi dan secara langsung dapat dipergunakan sebagai air minum. Air tanah ini dapat diambil dengan pompa tanah maupun pompa mesin.

\section{Kualitas Air Minum}

\section{Air Minum}

Air minum adalah air yang melalui proses pengolahan atau tanpa proses pengolahan yang memenuhi syarat kesehatan dan dapat langsung diminum.

Persyaratan Kualitas Air Minum

Berdasarkan Peraturan Menteri Kesehatan Republik Indonesia No. 492/ Menkes / Per/ IV/ 2010. Persyaratan 
Fisika, Kimia dan Mikrobiologi air minum sebagai berikut:

Kualitas Air Minum Secara Fisik

Suhu Normal

Air yang baik harus memiliki temperatur sama dengan temperatur udara $\left(3^{0} \mathrm{C}\right)$. Air yang secara mencolok mempunyai temperatur di atas atau di bawah temperatur udara berarti mengandung zat zat tertentu yang mengeluarkan atau menyerap energi dalam air. Berdasaran aspek suhu air, suhu air yang tidak sejuk atau berlebihan dari suhu air yang normal akan mempermudah reaksi zat kimia. Sehingga secara tidak langsung berimplikasi terhadap keadaan kesehatan pengguna air (Slamet dalam Rini 2014:16)

Kekeruhan

Air yang berkualitas harus memenuhi persyaratan fisik seperti jernih atau tidak keruh. Air yang keruh disebabkan mengandung partikel bahan yang tersuspensi sehingga memberikan warna/rupa yang berlumpur dan kotor.
Untuk standar air bersih ditetapkan oleh Permenkes RI No.492/ Menkes/ Per/ IV/ 2010, yaitu kekeruhan yang dianjurkan maksimum 5 NTU. Kekeruhan air disebabkan oleh zat padat yang tersuspensi, baik yang bersifat organik, maupun an organik. Zat organik biasanya berasal dari lapukan tanaman atau hewan, dan buangan industri juga berdampak terhadap kekeruhan air, sedangkan zat organik dapat mnjadi makanan bakteri, sehingga mendukung pembiakannya dan dapat tersuspensi dan menambah kekeruhan air. Air yang keruh sulit untuk didisinfeksi karena mikroba terlindung oleh zat tersuspensi tersebut, sehingga berdampak terhadap kesehatan, bila mirkroba terlindung dari atogen (Soemirat 2009).

Tidak mengandung zat padatan

Bahan padat adalah bahan yang tertinggal sebagai residu pada penguapan dan pengeringan pada suu $103-105^{\circ} \mathrm{C}$. Berikut ini tabel Persyaratan Kualitas Air Minum Secara Fisik berdasarkan Peraturan Menteri Kesehatan RI No. 492/ Menkes/ Per/ IV/ 2010 Tentang persyaratan kualitas air minum.

Tabel 1.2 Daftar Persyaratan Kualitas Air Minum Secara Fisik

\begin{tabular}{llll}
\hline No & Parameter & Kadar Maksimum & Satuan \\
\hline 1 & Suhu & $24-30$ & ${ }^{0} \mathrm{C}$ \\
\hline 2 & Warna & 15 & TCU \\
\hline 3 & Bau & Tidak Berbau & \\
\hline 4 & Rasa & Tidak Berasa & \\
\hline 5 & Kekeruhan & 5 & NTU \\
\hline 6 & $\begin{array}{l}\text { Jumlah Zat Padat Terlarut } \\
\text { (TDS) }\end{array}$ & 500 & $\mathrm{Mg} / \mathrm{lt}$ \\
\hline
\end{tabular}

Kualitas Air Minum Secara Kimia

Berikut tabel Persyaratan Kualitas Air Minum Secara Kimia berdasarkan Peraturan Menteri Kesehatan RI No. 492/ Menkes/
Per/ IV/ 2010 Tentang persyaratan kualitas air minum. 
Jurnal Penelitian Pendidikan Geografi Volume 4 No 2 April 2018

Tabel 1.3 Daftar Persyaratan Kualitas Air Minum Secara Kimia

\begin{tabular}{llll}
\hline No & Parameter & $\begin{array}{l}\text { Kadar Maksimum yang } \\
\text { Diperbolehkan }\end{array}$ & Satuan \\
\hline 1 & Air Raksa & 0,001 & $\mathrm{Mg} / \mathrm{lt}$ \\
\hline 2 & Arsen & 0,01 & $\mathrm{Mg} / \mathrm{lt}$ \\
\hline 3 & Besi & 0,3 & $\mathrm{Mg} / \mathrm{lt}$ \\
\hline 4 & Fluorida & 1,5 & $\mathrm{Mg} / \mathrm{lt}$ \\
\hline 5 & Kadnium & 0,003 & $\mathrm{Mg} / \mathrm{lt}$ \\
\hline 6 & Kesadahan $\left(\mathrm{CaCO}_{3}\right)$ & 500 & $\mathrm{Mg} / \mathrm{lt}$ \\
\hline 7 & Klorida & 250 & $\mathrm{Mg} / \mathrm{lt}$ \\
\hline 8 & Total Kromium & 0,05 & $\mathrm{Mg} / \mathrm{lt}$ \\
\hline 9 & Mangan & 0,4 & $\mathrm{Mg} / \mathrm{lt}$ \\
\hline 10 & Nitrat & 50 & $\mathrm{Mg} / \mathrm{lt}$ \\
\hline 11 & Nitrit & 3 & $\mathrm{Mg} / \mathrm{lt}$ \\
\hline 12 & Ph & $6,5-8,5$ & $\mathrm{Mg} / \mathrm{lt}$ \\
\hline 13 & Selenium & 0,1 & $\mathrm{Mg} / \mathrm{lt}$ \\
\hline 14 & Seng & 3 & $\mathrm{Mg} / \mathrm{lt}$ \\
\hline 15 & Sianida & 0,07 & $\mathrm{Mg} / \mathrm{lt}$ \\
\hline 16 & Sulfat & 250 & $\mathrm{Mg} / \mathrm{lt}$ \\
\hline 17 & Timbal & 0,01 & $\mathrm{Mg} / \mathrm{lt}$ \\
\hline
\end{tabular}

Kualitas Air secara Bakteriologi

Kualitas Mikrobiologi

Air untuk keperluan minum yang sehat harus bebas dari segala bekteri, terutama bakteri patogen (Notoatmojo, 2003). Bakteri golongan Coli (Coliform Bactery) tidak merupakan bakteri patogen, tetapi bakteri ini merupakan indikator dari pencemaran air oleh bakteri patogen. Menurut Permenkes RI No. 416/MENKES/PER/IX/1990, bakteri coliform yang memenuhi syarat untuk air bersih bukan perpipaan adalah <50 MPN. Standar air minum di Indonesia mengikuti standar WHO yang dalam beberapa hal disesuaikan dengan kondisi di Indonesia.
Pada tahun 2010, Departemen Kesehatan RI telah menetapkan kriteria kualitas air secara mikrobiologis, melalui Permenks RI No 492 /2010 bahwa air minum tidak diperbolehkan mengandung bakteri coliform dan Escherichia Coli. secara mikrobiologi, salah satu syarat air bersih yang dapat dikonsumsi adalah tidak ditemukannya Escherichia Coli dalam $100 \mathrm{ml}^{3}$. Escherichia Coli juga termasuk bakteri yang dapat menyebabkan keluhan diare.

Berikut Persyaratan Kualitas air minum secara mikrobiologi berdasarkan Peraturan Menteri Kesehatan RI No. 492/Menkes/Per/IV/2010 Tentang persyaratan kualitas air minum.

Tabel 1.4 Persyaratan Kualitas air minum secara mikrobiologi

\begin{tabular}{llll}
\hline No & Parameter & Satuan & $\begin{array}{l}\text { Kadar } \\
\text { Maksimum }\end{array}$ \\
\hline 1 & Total Bakteri Koliform & $/ 100 \mathrm{ml}$ & 0 \\
\hline 2 & Escheria Coli & $/ 100 \mathrm{ml}$ & 0 \\
\hline
\end{tabular}

Pemetaan (spasial) mengenai lingkungan. Pemetaan adalah suatu proses penyajian informasi muka bumi yang fakta (dunia nyata), baik 
bentuk permukaan buminya maupun sumbu alamnya, berdasarkan skala peta, sistem proyeksi peta, serta simbol-simbol dari unsur muka bumi yang disajikan (Jatmiko, 2011).

Sistem Informasi Geografi (SIG)

SIG adalah sistem berbasis komputer yang didesain untuk mengumpulkan mengelola, memanipulasi, menganalisis, dan menampilkan informasi spasial. aksud dan tujuan penggunaan SIG adalah untuk menciptakan suatu sistem kerja yang efektif dan efisien serta memudahkan dalam perencanaan, pemantauan, pemeliharaan, pengembangan dan membantu dalam pengambilan keputusan.

SIG merupakan sebuah sistem yang saling berangkaian satu dengan lainnya. SIG sebagai software yang memiliki kumpulan yang terorganisir dari perangkat keras komputer, perangkat lunak, data geografi, dan personel yang didesain untuk memperoleh, menyimpan, memperbaiki, memanipulasi, menganalisis, dan menampilkan semua bentuk informasi yang berreferensi geografi (Budiyanto, 2002).

\section{METODE PENELITIAN}

Jenis Penelitian

Jenis penelitian ini merupakan jenis penelitian kualitatif deskriptif, dengan metode atau pendekatan studi kasus (case study). Penelitian ini memusatkan diri secara intensif pada suatu obyek tertentu yang mempelajarinya sebagai suatu kasus. Data studi kasus dapat diperoleh dari semua pihak yang bersangkutan, dengan kata lain data dalam studi ini dikumpulkan dari berbagai sumber (Nawawi, 2003). Sebagai sebuah studi kasus, maka data yang dikumpulkan berasal dari berbagai sumber dan hasil penelitian ini hanya berlaku pada kasus yang diselidiki. Lebih lanjut arikunto (1986) mengemukakan bahwa metode studi kasus sebagai salah satu jenis pendekatan deskriptif, adalah penelitian yang dilakukan secara intensif, terperinci dan mendalam terhadap suatu organisme (individu), lembaga atau gejala tertentu dengan daerah atau subjek yang sempit.

\section{Tempat dan Waktu Penelitian}

Penelitian ini telah dilakukan di Kelurahan Wowawanggu Kecamatan Kadia Kota Kendari setelah disetujui pada seminar proposal. Tempat-tempat pengambilan sampel air tanah masing-masing satu titik di setiap RT yang terdiri dari 5 RT yakni RT 01 RW 01, RT 15 RW 02, dan RT 09 RW 03, RT 13 RW 04, dan RT 15 RW 05. Sampel yang diambil dari setiap sumur bor warga selanjutnya disimpan ke dalam botol plastik sebelum dilakukan analisis laboratorium.

Sampel Penelitian

Obyek dalam penelitian adalah air tanah dalam atau sumur bor yang memiliki kedalaman 50-100 meter yang terletak di Kelurahan Wowawanggu, Kecamatan Kadia, yakni RT 01 RW 01, RT 06 RW 02, dan RT 09 RW 03, RT 13 RW 04, dan RT 15 RW 05 . Teknik pengambilan sampel ditentukan dengan teknik purposive sampling. Teknik Purposive sampling merupakan teknik penentuan sampel dengan pertimbangan tertentu yakni sumber data dianggap paling tahu tentang apa yang diharapkan (Sugiono, 2008).

Instrumen Penelitian

Tabel 2.1 Alat dan Bahan

\begin{tabular}{|c|c|c|}
\hline No & Nama Alat/Bahan & Fungsi \\
\hline 1 & Termometer Air Raksa & Untuk mengukur suhu air sampel \\
\hline 2 & $\mathrm{pH}$ meter & Digunakan \\
\hline
\end{tabular}


Jurnal Penelitian Pendidikan Geografi Volume 4 No 2 April 2018

\begin{tabular}{llll}
\hline & & \multicolumn{2}{l}{ keasaman atau kebasaan air } \\
\hline 3 & HP & $\begin{array}{l}\text { Untuk mendokumentasikan } \\
\text { pengukuran di lapangan }\end{array}$ & kegiatan \\
\hline 3 & Air sampel & Sebagai bahan yang akan diamati & \\
\hline 4 & Botol Aquades & Untuk menyimpan air sampel & \\
\hline 5 & Turbidmeter & $\begin{array}{l}\text { Alat yang digunakan untuk memeriksa } \\
\text { tingkat kekeruhan air }\end{array}$ \\
\hline 6 & GPS & Untuk menentukan titik koordinat sampel \\
\hline 7 & TDS Meter & $\begin{array}{l}\text { Untuk mengukur kadar logam dalam air dan } \\
\text { zat padat terlarut lainnya. }\end{array}$ \\
\hline 8 & Timbangan Analitik & $\begin{array}{l}\text { Untuk mengukur kandungan padatan terlarut } \\
\text { (TDS) }\end{array}$ \\
\hline 9 & Labu Erlenmeyer & $\begin{array}{l}\text { Untuk proses titrasi untuk menampung } \\
\text { larutan yang akan dititrasi. }\end{array}$ \\
\hline
\end{tabular}

Prosedur Kerja

Cara Kerja Pengukuran Suhu:

1. Sampel air dituang dalam wadah botol aquades.

2. Memasukkan termometer ke dalam botol

3. Baca dan dicatat temperaturnya (waktu membaca thermometer tetap dalam air).

Cara Kerja Pengukuran pH:

1. Sampel air dituang dalam wadah botol aquades

2. Memasukkan $\mathrm{pH}$ meter ke dalam botol

3. Baca dan dicatat nilai yang diperoleh

Cara Kerja Pengukuran Kekeruhan:

1. Disiapkan sampel air sumur yang akan dianalisis

2. Dimasukan dalama rabung reaksi

3. Disiapkan alat turbdimeter

4. Diukur kekeruhan air sumur

Cara Kerja Pengukuran Kadar Besi (Fe)

1. Tahap preparasi sampel:

Sampel air sumur diambil $100 \mathrm{ml}$, kemudian dimasukan dalam gelas beker kemudian ditambah dengan HNO pekat : Hcl pekat dengan perbandingan 1:3, diencerkan dengan aquadest sampai tercapai $\mathrm{pH}$ asam (dibawah $<5$ ) kemudian sampel siap dititrasi dengan larutan standar EDTA $100 \mathrm{ppm}$

\section{Pengukuran sampel}

Larutan stok besi nitrat $\mathrm{Fe}(\mathrm{NO} 3)$ dengan konsentrasi 1000 ppm. Seri konsentrasi larutan baku $\mathrm{Fe} 0,0 \mu \mathrm{g} / \mathrm{ml}$, $0,05 \mu \mathrm{g} / \mathrm{ml}, 0,1 \mu \mathrm{g} / \mathrm{ml}, 0,2 \mu \mathrm{g} / \mathrm{ml}, 0,4 \mu \mathrm{g} / \mathrm{ml}$, $0,8 \mu \mathrm{g} / \mathrm{ml}$. masing -masing larutan yang telah dibuat pada panjang gelombang untuk logam besi. diukur kadar besinya dengan menggunakan AAS.

Cara Kerja Pengukuran Kadar Seng (Zn):

1. Tahap preparasi sampel:

Sampel air sumur diambil $100 \mathrm{ml}$, kemudian dimasukan dalam gelas beker kemudian ditambah dengan $\mathrm{HNO}$ pekat : Hcl pekat dengan perbandingan 1:3, diencerkan dengan aquadest sampai tercapai $\mathrm{pH}$ asam (dibawah < 5 ) kemudian sampel siap dititrasi dengan larutan standar EDTA 100 ppm

2. Pengukuran sampel

Larutan stok besi nitrat $\mathrm{Zn}$ (NO3) dengan konsentrasi 1000 ppm. Seri konsentrasi larutan baku $\mathrm{Zn} 0,0 \mu \mathrm{g} / \mathrm{ml}$, $0,05 \mu \mathrm{g} / \mathrm{ml}, 0,1 \mu \mathrm{g} / \mathrm{ml}, 0,2 \mu \mathrm{g} / \mathrm{ml}, 0,4 \mu \mathrm{g} / \mathrm{ml}$, $0,8 \mu \mathrm{g} / \mathrm{ml}$. masing -masing larutan yang telah dibuat pada panjang gelombang untuk logam seng. diukur kadar besinya dengan menggunakan AAS . 
Jurnal Penelitian Pendidikan Geografi Volume 4 No 2 April 2018

1. Cara Kerja Pengukuran Kesadahan $(\mathrm{Mg}$ $\mathrm{CaCO}_{3}$ )

2. Larutan sampel dalam kondisi asam, $\mathrm{pH}$ $=2$, dihomogenkan lalu disaring dan dibagi menjadi 2 .

3. Larutan sampel bagian pertama diambil $50 \mathrm{ml}$ lalu dimasukan dalam gelas beker $100 \mathrm{ml}$ dan dipanaskan hingga setengahnya. setelah dingin, larutan disaring lalu dimasukan dalam labu takar $50 \mathrm{ml}$. kemudian larutan ditambahkan akuades hingga tanda tera. setelah itu, larutan dipipet $10 \mathrm{ml}$ lalu dimasukan dalam labu ukur $50 \mathrm{ml}$, kemudian ditambahkan larutan buffer ionisasi $10 \mathrm{ml}$ dan akuades hingga tanda tera. selanjutnya, larutan sampel tersebut siap dianalisis dengan $\mathrm{Ca}$ dan $\mathrm{Mg}$ nya dengan menggunakan spektrofotometri Uv Vis.

4. Larutan sampel bagian ke 2 diambil 10 $\mathrm{ml}$ dimasukan ke dalam labu ukur $50 \mathrm{ml}$, kemudian, ditambahkan larutan buffer ionisasi $10 \mathrm{ml}$ dan akuades hinnga tanda tera. setelah itu, larutan sampel diukur kadar $\mathrm{Ca}$ dan $\mathrm{Mg}$ nya dengan menggunakan spektrofotometri Uv Vis. serapan kalsium diukur pada daerah 422 , 7 nm. sedangkan magnesium pada kisaran panjang gelombang $285,2 \mathrm{~nm}$.

Cara Kerja Pengukuran Kandungan Zat Terlarut (TDS):

1. disiapkan sampel air sumur yang akan dianalisis

2. dimasukan dalama gelas kimia

3. disiapkan alat TDS meter

4. diukur nilai tds pada sampel air sumur

Cara Kerja Eschericia Coli:

1. ditimbang agar 2 gram, $\mathrm{NaCl} 0,75$ gran B.E (beef extrak) 0, 35 gram, dan pepton 0,75 gram.

2. Dimasukan dalam labu erlemeyer $500 \mathrm{ml}$, lalu ditambahkan akuades sebangak 200 $\mathrm{ml}$.
3. Panaskan hingga mendidih

4. Setelah itu didinginkan dalam suhu ruangan

5. Tutup mulut labu dengan kapas dan kasa lalu direp

6. Autoklaf selama 7 jam bersamaan dengan alat-alat yang digunakan untuk sterilisasi alat dan bahan

7. Dikeluarkan dari alat autoclafnya lalu dimasukan dalam lemari incubator

8. Siapkan 5 pasang capet lalu dituangkan 5 $\mathrm{ml}$ larutan media sampai mongering lalu dimbahkan $1 \mathrm{ml}$ air sampel.

9. Setelah itu capet di rep lalu dibungkus dengan kertas korang, diulangi prosedur ini untuk sampel 2, 3. 4, dan 5.

10. Simpan dalam lemari kayu hingga 2 hari

11. Keluarkan capetnya lalu diamati dengan menggunakan mikroskop elektronik agar diketahui jumlah bakteri ecolinya. Jumlah bakteri ecolinya (\%): sampel $1(0,79)$, sampel $2(1,37)$, sampel 3 (1,09), sampel $4(0,98)$, smpel 5 (1.28).

Cara Kerja Total Koliform:

1. Ditimbang agar 2 gram, $\mathrm{NaCl} 0,75$ gran B.E (beef extrak) 0, 35 gram, dan pepton 0,75 gram.

2. Masukan dal labu erlemeyer $500 \mathrm{ml}$, lalu ditambahkan akuades sebangak $200 \mathrm{ml}$

3. Panaskan hingga mendidih

4. Setelah itu didinginkan dalam suhu ruang

5. Saring dengan menggunakan penyaring membran

6. Tutup mulut labu dengan kapas dan kasa lalu direp

7. Autoklaf selama 7 jam bersamaan dengan alat alat yang digunakan untuk sterilisasi alat dan bahan

8. Keluarkan dari alat autoclafnya lalu dimasukan dalam lemari incubator

9. Siapkan 5 pasang capet lalu dituangkan 5 ml larutan media sampai mengering lalu ditambahkan $1 \mathrm{ml}$ air sampel. 
Jurnal Penelitian Pendidikan Geografi Volume 4 No 2 April 2018

10. setelah itu capet direp lalu dibungkus dengan kertas koran, diulangi prosedur ini untuk sampel 2, 3, 4, dan 5.

11. disimpan dalam lemari kayu hingga 2 hari

12. dikeluarkan capetnya lalu diamati dengan menggunakan mikroskop elektronik.

13. diukur pHnya untuk mengamati perubahan laktosa $\mathrm{m} \quad$ enjadi gas.
Teknik Analisis Data

Analisis pada air ini dilakukan di laboratorium. Analisis laboratorium meliputi parameter fisika yang terdiri dari: suhu, kekeruhan dan TDS dan parameter kimia yang terdiri dari: $\mathrm{pH}$, besi $(\mathrm{Fe})$, seng (Zn) dan kesadahan $\left(\mathrm{Mg} \mathrm{CaCO}_{3}\right)$, Serta parameter Mikrobiologi yaitu total bakteri coliform dan Escherichia coli.

\section{HASIL PENELITIAN}

Tabel 3.1 Data hasil pengukuran sampel di laboratorium

\begin{tabular}{|c|c|c|c|c|c|c|c|c|}
\hline \multirow{2}{*}{ No } & \multirow{2}{*}{ Parameter } & \multirow{2}{*}{ Satuan } & \multirow{2}{*}{$\begin{array}{l}\text { Standar } \\
\text { Maksim } \\
\text { um }\end{array}$} & \multicolumn{5}{|c|}{ Hasil Pengukuran } \\
\hline & & & & $\begin{array}{l}\text { Sumur } \\
1\end{array}$ & $\begin{array}{l}\text { Sumur } \\
2\end{array}$ & $\begin{array}{l}\text { Sumur } \\
3\end{array}$ & $\begin{array}{l}\text { Sumur } \\
4\end{array}$ & $\begin{array}{l}\text { Sumur } \\
5\end{array}$ \\
\hline . & Fisik & & & & & & & \\
\hline 1 & Suhu & ${ }^{0} \mathrm{C}$ & $24-30$ & $27^{0}$ & $27^{0}$ & $28^{0}$ & $28^{0}$ & $27^{0}$ \\
\hline 2 & Kekeruhan & NTU & 5 & 3,2 & 3,7 & 3,4 & 3,3 & 3,9 \\
\hline 3 & TDS & $\mathrm{Mg} / \mathrm{L}$ & 500 & 8,39 & 8,52 & 8,49 & 8,48 & 8,52 \\
\hline B. & Kimia & & & & & & & \\
\hline 4 & $\mathrm{Ph}$ & $\mathrm{Mg} / \mathrm{L}$ & $6,5-8,5$ & 7 & 7 & 7 & 6 & 7 \\
\hline 5 & Besi & $\mathrm{Mg} / \mathrm{L}$ & 0,3 & 1,306 & 1,746 & 1,371 & 1,482 & 1,816 \\
\hline 6 & Seng & $\mathrm{Mg} / \mathrm{L}$ & 3 & 0,947 & 0,667 & 0,588 & 1,032 & 1,119 \\
\hline 7 & Kesadahan & $\mathrm{Mg} / \mathrm{L}$ & 500 & $\begin{array}{l}93,812 \\
61\end{array}$ & $\begin{array}{l}159,482 \\
53\end{array}$ & $\begin{array}{l}113,415 \\
62\end{array}$ & $\begin{array}{l}90,362 \\
76\end{array}$ & $\begin{array}{l}146,509 \\
44\end{array}$ \\
\hline $\mathrm{C}$ & Mikrobiologi & & & & & & & \\
\hline 8 & Escheria Coli & $\begin{array}{l}/ 100 \\
\mathrm{ml}\end{array}$ & 0 & 0,79 & 1,37 & 1,09 & 0,98 & 1,28 \\
\hline 9 & $\begin{array}{l}\text { Total } \\
\text { Coliform }\end{array}$ & $\begin{array}{l}/ 100 \\
\mathrm{ml}\end{array}$ & 0 & 55,33 & 65,35 & 49,69 & 42,33 & 96,42 \\
\hline
\end{tabular}

Gambaran Kualitas Fisik Air Sumur Bor

Berdasarkan hasil analisis diperoleh bahwa kelima sampel air sumur bor yang diuji dengan menggunakan parameter fisika yaitu: parameter suhu, kekeruhan, dan TDS memenuhi syarat menurut Peraturan Menteri Kesehatan RI No. 492/Menkes/Per/IV/2010, dimana standar maksimum untuk suhu air minum yaitu 24$30^{\circ} \mathrm{C}$. Suhu air pada sampel pertama sebesar $27^{\circ} \mathrm{C}$, sampel kedua $27^{\circ} \mathrm{C}$, sampel ketiga $28^{\circ} \mathrm{C}$, sampel keempat $28^{\circ} \mathrm{C}$, dan sampel kelima $27^{\circ} \mathrm{C}$. Sehingga kelima sampel air tersebut jika dilihat dari parameter suhu telah memenuhi persyaratan untuk dikonsumsi. 
Pada hasil uji TDS air diperoleh hasil uji pada sampel pertama sebesar 8,39 $\mathrm{mg} / \mathrm{liter}$, sampel kedua $8,52 \mathrm{mg} / \mathrm{liter}$, sampel ketiga $8,49 \mathrm{mg} / \mathrm{liter}$, sampel keempat 8,48 $\mathrm{mg} / \mathrm{liter}$ dan sampel kelima sebesar 8,52 $\mathrm{mg} /$ liter. Hasil uji tersebut menunjukkan bahwa kelima sampel telah memenuhi syarat batas maksimum kadar TDS pada air minum, dimana batas maksimumnya adalah $500 \mathrm{mg} /$ liter menurut Peraturan Menteri Kesehatan RI No. 492/Menkes/Per/IV/2010.

Hasil uji parameter Kekeruhan terhadap kelima sampel air sumur bor menunjukkan bahwa semua sampel memenuhi syarat batas maksimum kekeruhan air yaitu 5 NTU. Kadar kekeruhan air pada sampel pertama sebesar 3,2 NTU, sampel kedua 3,7 NTU, sampel ketiga 3,4 NTU, sampel keempat 3,3 NTU, dan sampel kelima sebesar 3,9 NTU.

\section{Gambaran Kualitas Kimia Air Sumur Bor}

Berdasarkan hasil analisis diperoleh bahwa semua sampel yang diteliti memenuhi syarat kecuali pada parameter besi $(\mathrm{Fe})$, dimana batas maksimum kadar logam besi yang diperbolehkan untuk dikonsumsi adalah 0,3 $\mathrm{mg} /$ liter menurut Peraturan Menteri Kesehatan RI No. 492/Menkes/Per/IV/2010, sedangkan kadar besi $(\mathrm{Fe})$ pada kelima sampel air sumur bor melebihi batas maksimum yaitu sebesar 1,306 $\mathrm{mg} / \mathrm{liter}$ pada sampel pertama, 1,746 $\mathrm{mg} / \mathrm{liter}$ pada sampel kedua, $1,371 \mathrm{mg} / \mathrm{liter}$ sampel ketiga, 1,482 $\mathrm{mg} / \mathrm{liter}$ sampel keempat dan 1,816 mg/liter pada sampel kelima. Kadar besi tertinggi terdapat pada sampel kelima dan terendah terdapat pada sampel pertama. Dengan demikian, kadar besi $(\mathrm{Fe})$ air sumur bor kelima sampel tidak memenuhi syarat sebesar $100 \%$ artinya tidak ada satupun sampel yang memenuhi syarat untuk dikonsumsi jika dilihat dari kandungan logam besi. Hal ini diartikan bahwa air sumur yang digunakan warga telah terkontaminasi oleh logam besi $(\mathrm{Fe})$ dan tidak memenuhi syarat untuk diminum. Tingginya kadar besi (Fe) pada kedua sampel ini menunjukkan bahwa sampel air sumur bor tersebut telah tercemar oleh logam besi (Fe).
Gambaran Kualitas Mikrobiologi Air Sumur Bor

Hasil analisis menunjukkan bahwa kelima sampel air sumur bor yang diteliti tidak memenuhi syarat untuk dikonsumsi jika dilihat dari parameter Mikrobiologi yaitu bakteri Escherichia coli dan total koliform menurut Peraturan Menteri Kesehatan RI No. 492/Menkes/Per/IV/2010 Tentang Persyaratan Air minum, dimana batas maksimum kadar bakteri Escherichia Coli dan bakteri Total Koliform yang layak untuk dikonsumsi sebesar 0 MPN/100 mg/lt, sedangkan kelima sampel yang diteliti memiliki kadar lebih dari angka nol. Tingginya kadar bakteri Escerichia Coli dan Total Koliform ini dapat disebabkan oleh jarak pembuangan septic tank yang cukup dengan dengan lokasi sumur bor.

\section{PEMBAHASAN}

Suhu air yang baik harus memiliki temperatur udara $\left(24-30^{\circ} \mathrm{C}\right)$ menurut Peraturan Menteri Kesehatan RI No. 492/Menkes/Per/IV/2010. Air yang sudah tercemar mempunyai temperatur di atas atau di bawah temperatur udara. Sampel air pada kelima lokasi tersebut mempunyai rentang antara $27-28^{\circ} \mathrm{C}$. Hasil pengujian ini menunjukkan bahwa air sumur bor dari ke lima lokasi tersebut memenuhi syarat air bersih untuk digunakan sebagai air minum sesuai kriteria menurut Peraturan Menteri Kesehatan RI No. 492/Menkes/Per/IV/2010 Tentang persyaratan kualitas air minum.

Kekeruhan air menunjukkan adanya partikel-partikel dari tanah yang kemungkinan telah terkontaminasi logamlogam seperti besi (Fe), mangan (Mn), seng $(\mathrm{Zn})$, dan sebagainya. secara umum kekeruhan air dapat disebabkan oleh zat padat yang tersuspensi, baik bersifat organik, maupun an organik. Zat organik sebagian besar merupakan hasil degradasi secara biologis sisa-sisa tumbuhan maupun hewan contohnya humus. Sedangkan zat anorganik sebagian besar dihasilkan oleh proses cuaca/alam, sebagai contoh oksida besi $(\mathrm{Fe})$, kalsit maupun mineral lainnya. Standar parameter kekeruhan menurut Peraturan 
Menteri Kesehatan RI No. 492/Menkes/Per/IV/2010 maksimum adalah 5 NTU. Dari hasil analisis kekeruhan terhadap ke lima sumur didapatkan rentang nilai antara 3,2-3,9 sehingga dapat disimpulkan bahwa kelima sumur tersebut memenuhi standar parameter kekeruhan air menurut Peraturan Menteri Kesehatan RI No. 492/Menkes/Per/IV/2010 Tentang Persyaratan Kualitas Air Minum.

Derajat Keasaman $(\mathrm{pH})$ air yang lebih kecil dari 6,5 atau $\mathrm{Ph}$ asam meningkatkan korositas pada benda-benda logam, menimbulkan rasa tidak enak dan dapat menyebabkan beberapa bahan kimia menjadi racun yang mengganggu kesehatan. Hasil pengujian pada sumur pertama sampai pada sumur kelima memiliki nilai $\mathrm{pH}$ antara 6-7. Hasil pengujian ini menunjukkan bahwa air sumur bor dari kelima lokasi memenuhi syarat baku air miunum untuk $\mathrm{pH}$ sesuai dengan Peraturan Menteri Kesehatan RI No. 492/Menkes/Per/IV/2010

Tentang

persyaratan kualitas air minum.

Besi atau Ferrum (Fe) adalah metal berwarna abu-abu, liat dan dapat dibentuk. Besi (Fe) merupakan elemen kimia yang dapat ditemukan hampir di setiap tempat di bumi. Namun besi juga dapat berbahaya apabila kadarnya melampaui ambang batas. Berdasarkan hasil penelitian terhadap kelima sampel air sumur bor, kadar besi air berkisar antara 1,306-1,816 mg/liter dimana standar maksimum untuk kadar besi $(\mathrm{Fe})$ menurut Peraturan Menteri Kesehatan RI No. 492/Menkes/Per/IV/2010 adalah 0,3, sehingga dapat disimpulkan bahwa air sumur bor di Kelurahan Wowawanngu Kecamatan Kadia belum memenuhi Persyaratan kualitas air minum jika dilihat dari parameter besi. Nilai kadar besi air yang berlebihan di dalam tubuh manusia dapat merusak dinding usus dan sering mengakibatkan kematian. Dalam penyediaan air minum besi dapat menimbulkan rasa, menimbulkan warna, noda pada pakaian, bertumbuhnya bakteri besi dan kekeruhan. Hal ini dapat dipengaruhi oleh masyarakat yang membuang sampah logam sembarangan/ kegiatan perbengkelan yang membuang sampah oli sembarangan. sehingga masuk dalam tanah tetapi kadar di atas masih bisa diterima oleh tubuh asal tidak dikonsumsi secara langsung.

Dari hasil analisa diperoleh angka seng (Zn) pada sampel berkisar antara 1,306$1,816 \mathrm{mg} / \mathrm{L}$, Sehingga masih memenuhi standar kualitas air minum. Seng (Zn) dalam jumah kecil merupakan unsur penting dalam metabolisme, sehingga kalau anak kekurangan Seng (Zn), pertumbuhannya bisa terhambat. Seng (Zn) juga berperan dalam membantu penyembuhan luka, menyusun struktur protein dan membran sel. Namun terlalu banyak seng ( $\mathrm{Zn}$ ) akan menyebabkan rasa pahit dan sepet dalam air minum, dapat menyebabkan muntah, diare serta menyebabkan gangguan reproduksi.

Kesadahan adalah sifat air yang disebabkan oleh adanya ion-ion (kation) logam valensi dua (Sutrisno, 2004). tingginya kesadahan berhubungan dengan garam-garam yang terlarut di dalam air terutama garam Ca dan $\mathrm{Mg}$ (Asdak, 2004). Dari hasil analisa Tingkat kesadahan air sumur bor di kelurahan Wowawanggu Kecamatan Kadia diperoleh tingkat kesadahan sampel terendah yaitu pada sampel keempat di lintang $3^{0} 59^{\prime} 45.0^{\prime \prime}$ LS dan $122^{0} 30^{\prime} 22.5^{\prime \prime}$ BT sebesar 90,36276 dan sampel tertinggi terdapat pada sampel kelima di lintang $3^{0} 59^{\prime} 48.5$ ' LS dan $122^{0} 30$ '29.7' BT sebesar 146,50944. Angka kesadahan tersebut masih memenuhi standar kualias air minum dimana persyaratan kualitas air minum untuk nilai kesadahan yaitu maksimal $500 \mathrm{mg} / \mathrm{liter}$.

Bakteri Escherichia coli atau sering disingkat $E$. coli adalah bakteri yang umum ditemukan di dalam usus manusia. Bakteri ini terdiri beberapa jenis dan sebagian besar di antaranya tidak berbahaya. Itu artinya bahwa hanya segelintir jenis bakteri $E$. coli yang dapat merugikan kesehatan. Salah satu bakteri $E$. coli yang berbahaya adalah $E$. coli O157:H7. Bakteri ini bisa menyebabkan keracunan makanan dan infeksi yang cukup serius. E. coli $\mathrm{O} 157: \mathrm{H} 7$ dapat menghasilkan racun yang mampu merusak dinding dari usus kecil dan mengakibatkan kram perut, 
diare yang bercampur dengan darah, hingga muntah-muntah. Hasil analisis sampel air sumur bor di laboratorium menunjukkan bahwa kelima sampel air yang diauji positif mengandung bakteri Escherichia Coli, sebab kelima sampel memiliki kadar bakteri yang melebihi standar maksimum persyaratan air minum yaitu $0 \mathrm{MPN} / 100 \mathrm{ml}$. Adapun cara untuk membunuh jenis bakteri ini adalah dengan memanaskan air atau masakan hingga mencapai suhu 73,8 derajat Celcius agar dapat matang dengan sempurna sampai bagian terdingin.

Total Coliform merupakan indikator bakteri pertama yang digunakan untuk menentukan aman tidaknya air untuk dikonsumsi. Bila Total Coliform dalam air ditemukan dalam jumlah yang tinggi maka kemungkinan adanya bakteri patogenik seperti Giardia, dan Cryptosporidium di dalamnya. Menurut Kepmenkes RI No: 907/Menkes/VII/2002 kadar maksimum Total Coliform yang diperbolehkan dalam air minum adalah 0 MPN/100Ml, yang artinya bahwa keberadaan bakteri ini dalam air minum benar-benar tidak diizinkan. berdasarkan hasil analisis laboratorium, kelima sampel air sumur yang diuji tidak memenuhi persayatan untuk dikonsumsi dimana kadar bakteri Total Koliform memiliki rentang nilai 42,33 MPN/100 ml sampai 96,42 MPN/100 ml sedangkan, standar maksimum untuk dikonsumsi adalah 0 MPN/100 ml. maksimum untuk dikonsumsi adalah 0 MPN/100 $\mathrm{ml}$.

Peta sebaran Kualitas Air Sumur Bor

\section{Gambar 4.1 Peta titik lokasi sampel penelitian}

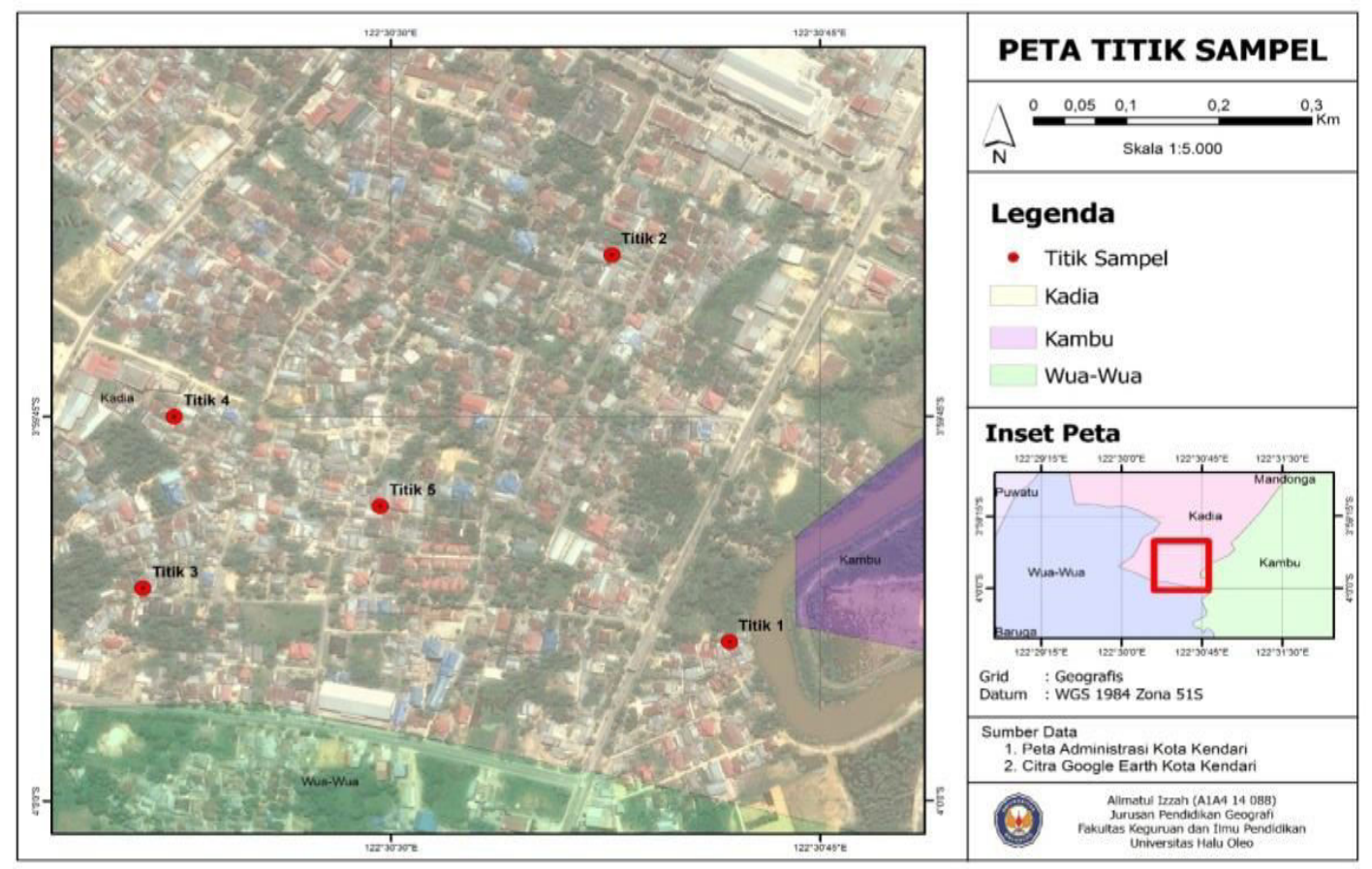

Sampel air sumur bor diambil dari lima titik lokasi yang berbeda. Titik lokasi pertama terletak di RT 13 RW 04, Titik kedua di RT 09 RW 03, titik ketiga di RT 01 RW 01, Titik keempat di RT 06 RW 02 dan titik lokasi kelima terletak di RT 15 RW 05. 
Jurnal Penelitian Pendidikan Geografi Volume 4 No 2 April 2018

Gambar 4.2 Peta Sebaran Derajat Suhu Air Sumur Bor

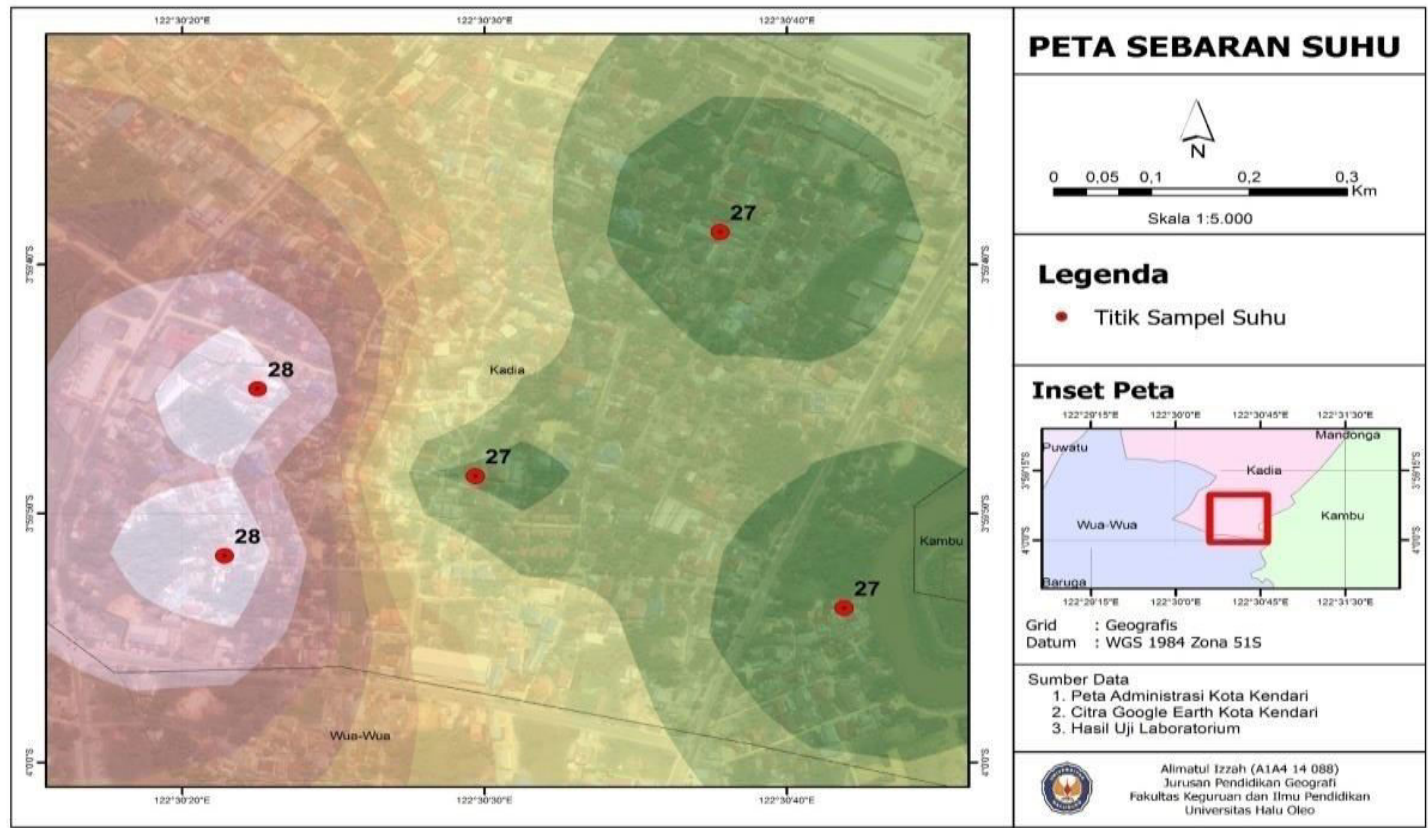

Pada peta dapat diamati bahwa derajat suhu air sumur bor yang diteliti berkisar antara $27-28^{\circ} \mathrm{C}$. Sampel air sumur bor pada sumur 1, 2 dan 5 memiliki suhu $27^{\circ} \mathrm{C}$, sedangkan sampel air sumur bor pada sumur 3 dan 4 memiliki suhu $28^{\circ} \mathrm{C}$.

Gambar 4.3 Peta sebaran tingkat kekeruhan air sumur bor

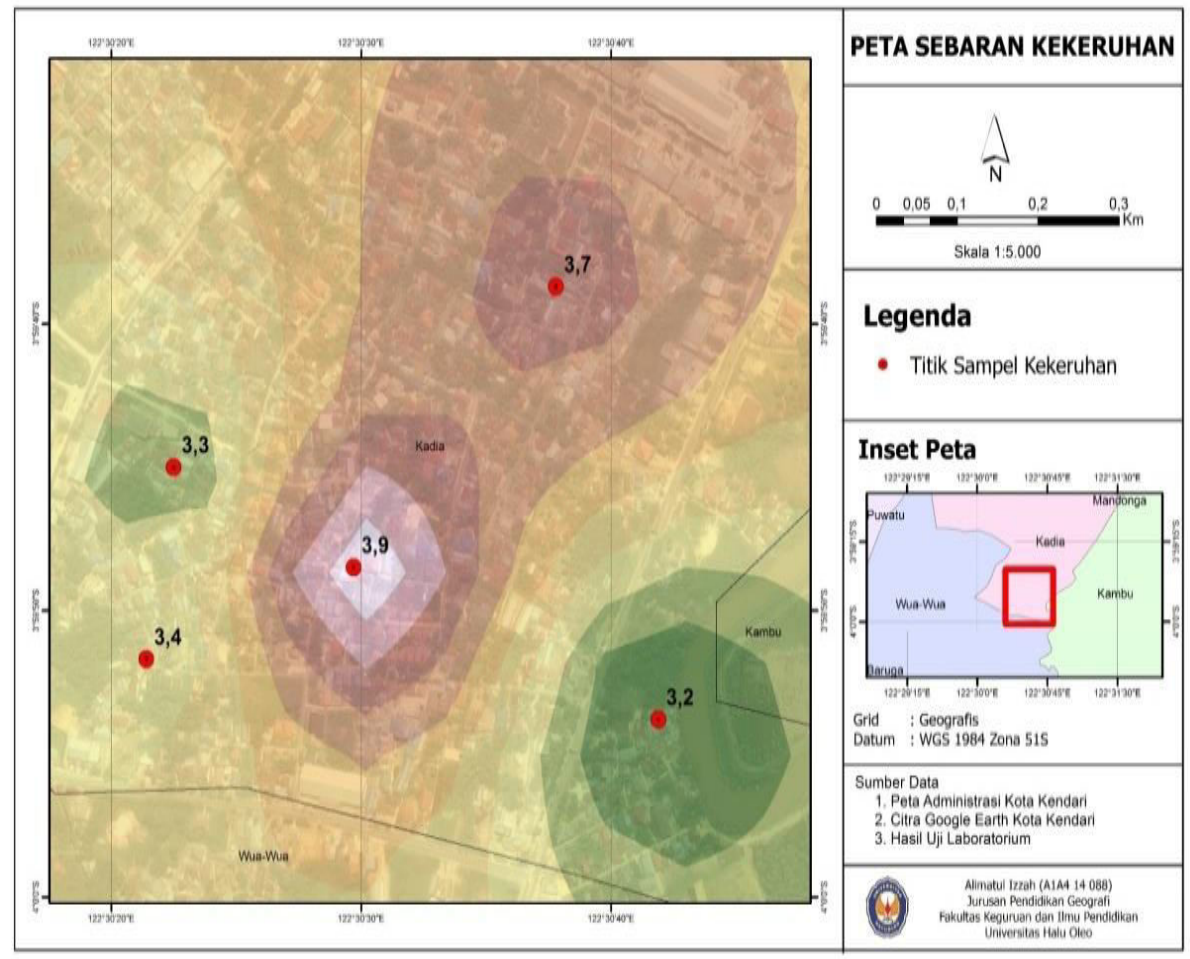

Alimatul Izzah 
Jurnal Penelitian Pendidikan Geografi Volume 4 No 2 April 2018

Dari peta di atas dapat disimpulkan bahwa sampel yang memiliki tingkat kekeruhan air sumur bor tertinggi terdapat pada sampel air sumur bor kelima pada lintang $3^{0} 59^{\prime} 48,5^{\prime \prime} \mathrm{LS}$ dan $122^{0} 30^{\prime} 29,7^{\prime \prime}$ BT dengan nilai 3,9 NTU. Sedangkan tingkat kekeruhan air terendah terdapat pada sampel pertama pada lintang $3^{0} 59^{\prime} 53,8^{\prime \prime} \mathrm{LS}$ dan $122^{0} 30^{\prime} 41,9$ ' BT dengan nilai 3,2 NTU.

Gambar 4.4 Peta Sebaran kadar TDS (Total Dissolve Solid) dalam air sumur bor

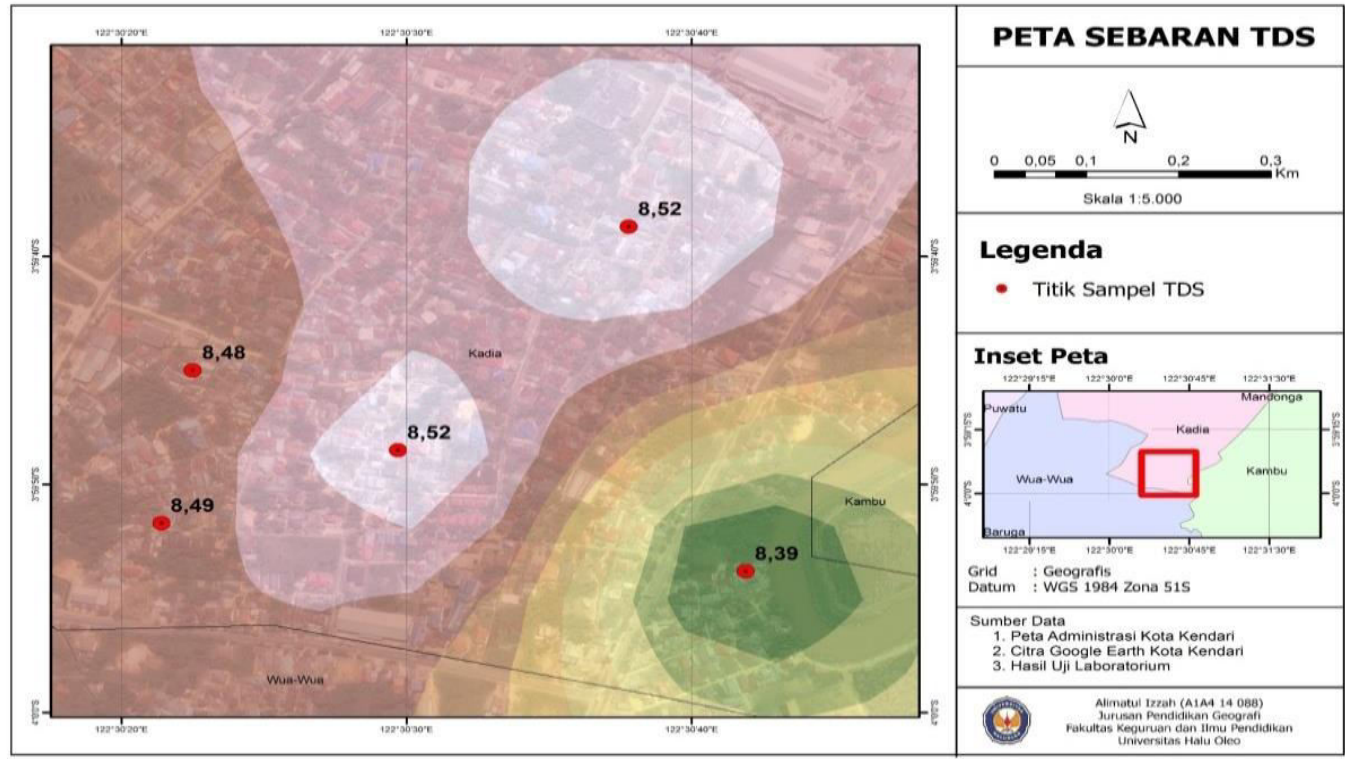

Dari peta sebaran TDS di atas dapat dilihat bahwa air sumur bor yang memiliki kadar TDS tertinggi terletak pada sampel kedua dan kelima dengan nilai 8,52 mg/liter. Sedangkan kadar TDS terendah terletak pada sampel satu dengan nilai $8,39 \mathrm{mg} /$ liter.

\section{Gambar 4.5 Peta Sebaran pH air sumur bor}

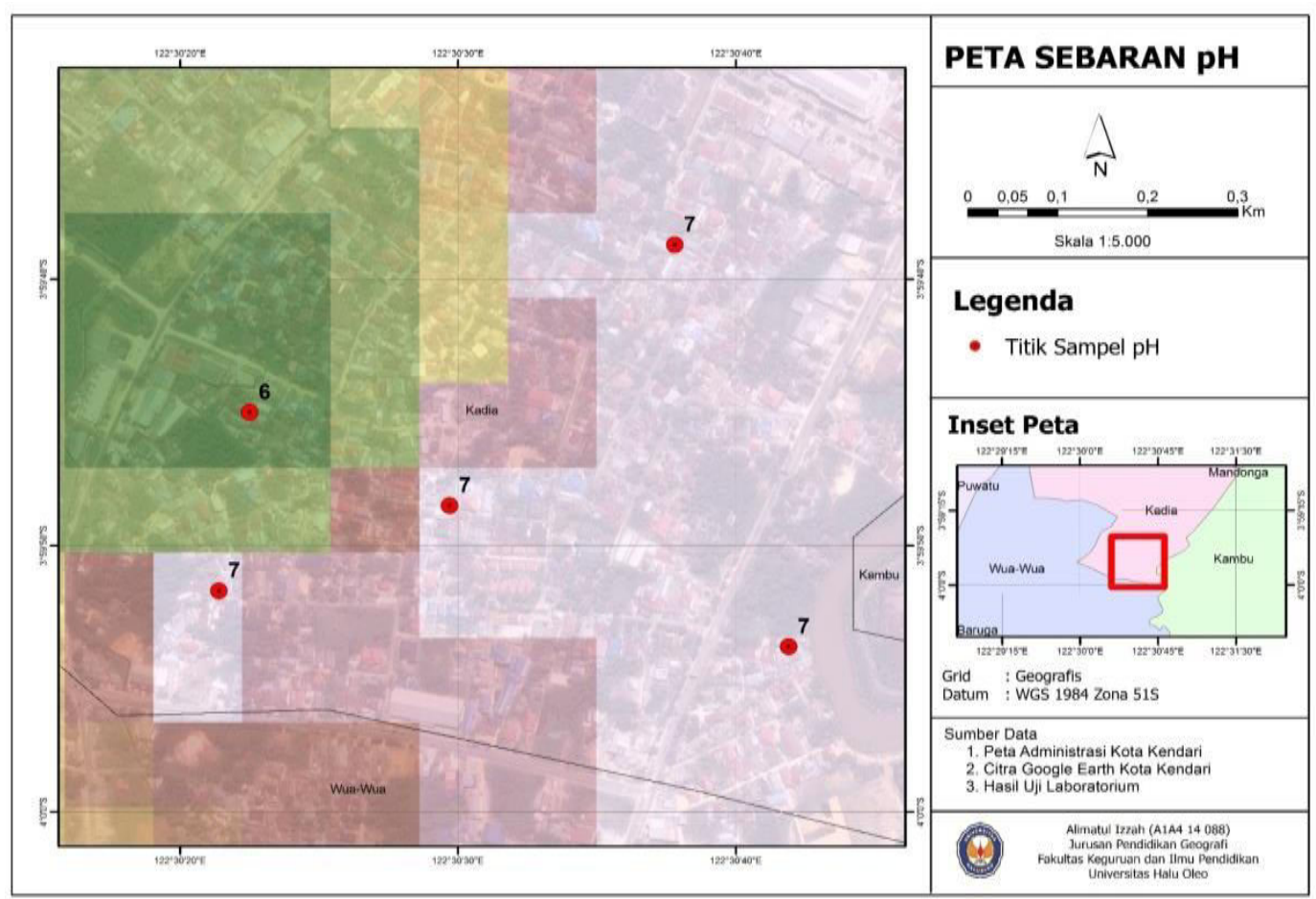


Jurnal Penelitian Pendidikan Geografi Volume 4 No 2 April 2018

Dari peta sebaran $\mathrm{pH}$ air sumur bor di atas dapat dilihat bahwa sampel air sumur bor yang diteliti rata rata memiliki nilai $\mathrm{pH} 7$ kecuali pada sampel ke empat yaitu pH 6.

\section{Gambar 4.6 Peta sebaran tingkat kesadahan air sumur bor}

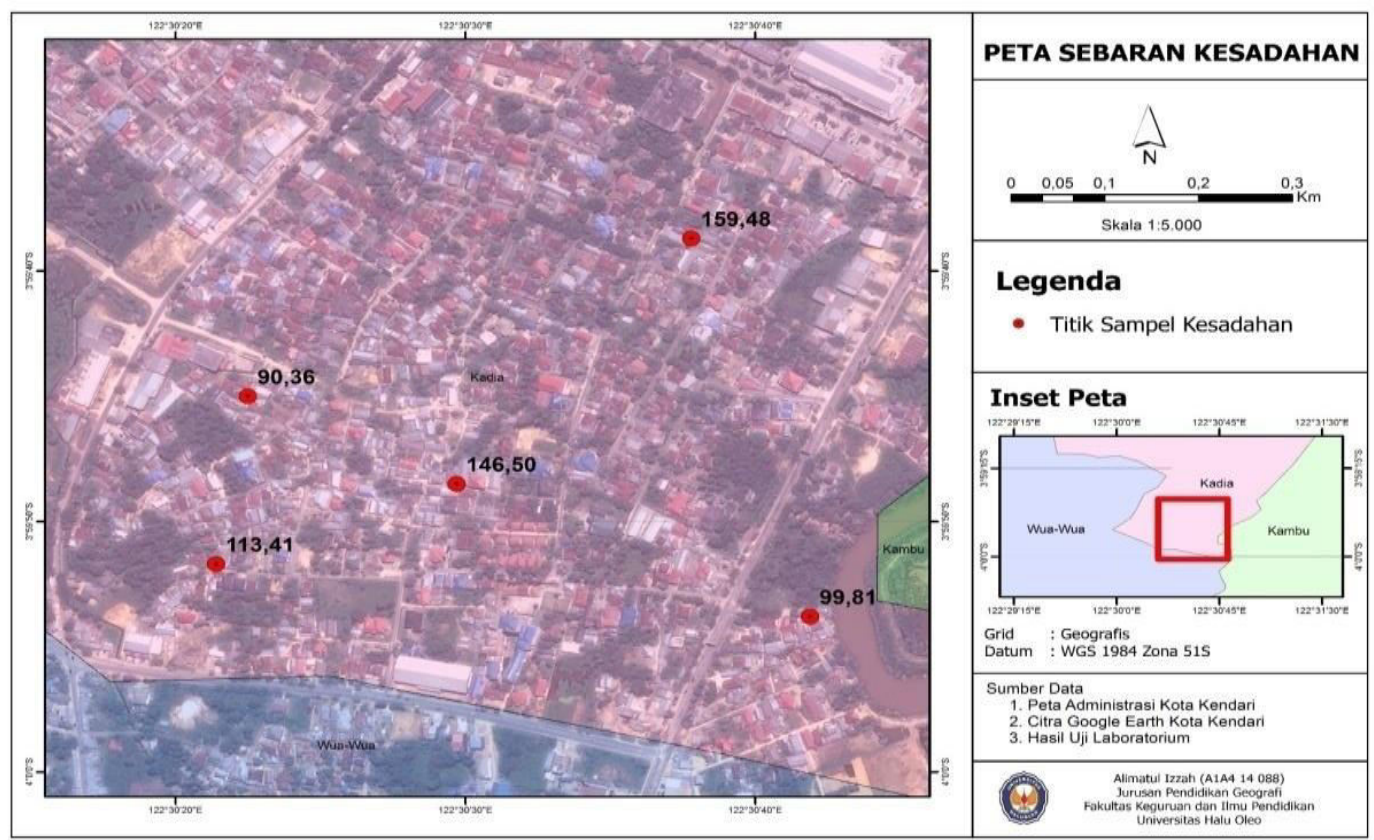

Dari peta di atas dapat dilihat bahwa sampel yang memiliki tingkat kesadahan air sumur bor tertinggi berada pada sampel kedua di lintang $3^{0} 59^{\prime} 38,7^{\prime}$ ' LS dan $122^{0} 30^{\prime} 37,8^{\prime \prime}$ BT dengan nilai 159,48 ppm.
Sedangkan sampel yang memiliki tingkat kesadahan terendah yaitu sampel ke empat di lintang $3^{0} 59^{\prime} 45,0^{\prime \prime}$ LS dan $122^{0} 30$ ' $22,5^{\prime}$ " BT dengan nilai 90,36 ppm.

\section{Gambar 4.7 Peta sebaran kadar bakteri total koliform air}

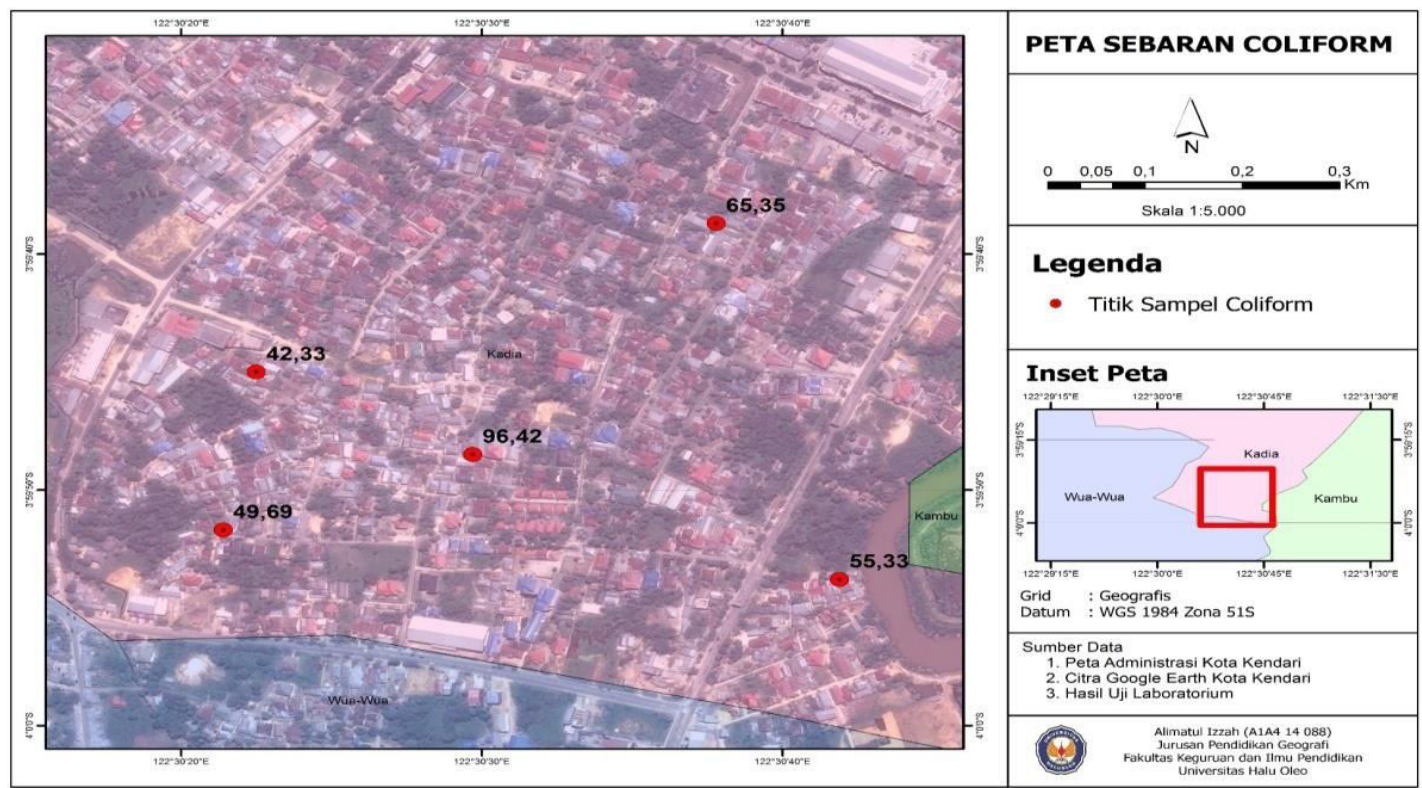


Dari peta sebaran kadar bakteri total coliform dapat dilihat bahwa kadar bakteri koliform tertinggi berada pada sampel ke lima pada lintang $3^{0} 59^{\prime} 48,5^{\prime \prime}$ LS dan $122^{0} 30^{\prime} 29,7$ ' BT dengan nilai 96,42 . Sedangkan sampel yang memiliki kadar bakteri koliform terendah yaitu pada sampel ke empat di lintang $3^{0} 59^{\prime} 45,0^{\prime \prime}$ LS dan $122^{0} 30^{\prime} 22,5$ ” BT dengan nilai 42,33.

\section{KESIMPULAN}

Berdasarkan hasil penelitian yang telah dilakukan, maka dapat diambil beberapa kesimpulan sebagai berikut:

Hasil uji kualitas air sumur bor dari parameter fisika yeng terdiri dari parameter suhu, kekeruhan dan TDS memenuhi syarat untuk dikonsumsi karena nilai ketiga parameter tersebut tidak melebihi ambang batas.

Hasil uji kualitas air air sumur bor dari parameter kimia yang terdiri dari parameter $\mathrm{pH}$, Seng ( $\mathrm{Zn}$ ), dan Kesadahan memenuhi persyaratan untuk dikonsumsi tetapi untuk parameter besi (Fe) tidak memenuhi syarat untuk dikonsumsi karena nilai kadar besi kelima sampel air sumur bor yang diuji melebihi standar maksimum persyaratan kualitas air minum untuk besi yaitu $0,3 \mathrm{mg} / \mathrm{liter}$. Adapun letak koordinat sampel yang tidak memenuhi syarat yaitu sampel satu pada lintang $3^{0} 59^{\prime} 53,8^{\prime}$ 'LS dan $122^{0} 30^{\prime} 41,9^{\prime \prime}$ BT, sampel dua pada $3^{0} 59^{\prime} 38$, 7' LS dan $122^{0} 30^{\prime} 41,9$ " BT, sampel tiga pada $3^{0} 59^{\prime} 51,7^{\prime}$ 'LS dan $122^{0} 30^{\prime} 21,4^{\prime \prime}$ BT, sampel empat pada $3^{0} 59^{\prime} 45,0^{\prime \prime}$ LS dan $122^{0} 30^{\prime} 22,5^{\prime \prime}$ BT, dan sampel lima terletak pada $3^{0} 59^{\prime} 48,5^{\prime}$ 'LS dan $122^{0} 30^{\prime} 29,7^{\prime \prime}$ BT.

Hasil uji kualitas air air sumur bor dari parameter mikrobiologi yang terdiri dari bakteri Escherichia coli dan total coliform tidak memenuhi syarat untuk dikonsumsi karena nilai kedua bakteri tersebut melebihi ambang batas kadar bakteri yang dipersyaratkan untuk air minum yaitu 0 $\mathrm{mg} / \mathrm{liter}$.

Ada 2 (dua) parameter yang tidak memenuhi syarat untuk dikonsumsi yaitu dari parameter kimia yaitu besi $(\mathrm{Fe})$, dan dari parameter mikrobiologi yaitu bakteri Escherichia coli dan total coliform.

\section{DAFTAR PUSTAKA}

Budiyanto, E. 2002. Sistem Informasi Geografis Menggunakan Arcview GIS. Andi Yogyakarta.

Notoatmodjo, S. 2003. Ilmu Kesehatan Masyarakat Prinsip-Prinsip Dasar. Rineka Cipta. Jakarta.

Peraturan Menteri Kesehatan Republik Indonesia Nomor 492/Menkes/Per/IV/2010

Rini, Fajar. 2014 Analisis Kualitas Air Tanah Masyarakat Di Sekitar Tempat Pembuangan Akhir (TPA) Sampah Kelurahan Sumur Batu Bantang Gebang Bekasi. Jakarta: Universitas Islam Negeri Jakarta.

Sugiono. 2008. Metode Penelitian Kuantitatif Kualitatif. Alfabeta. 